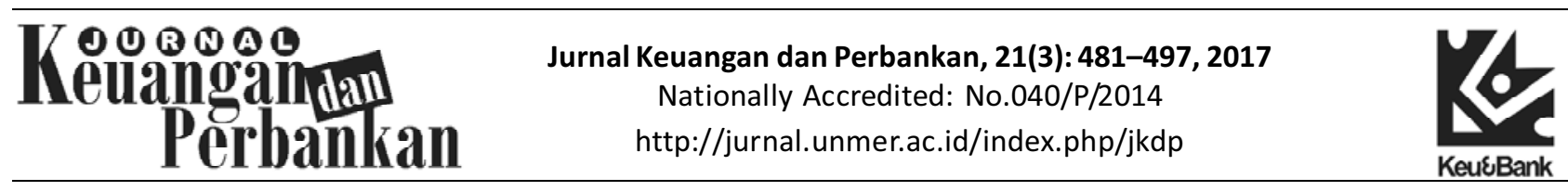

\title{
Perbandingan Pengelolaan Risiko Kredit Perbankan Syariah dan Perbankan Konvensional
}

\author{
Muhammad Iqbal \\ Departemen Manajemen Fakultas Ekonomi dan Bisnis Perbanas Institute \\ Jl. Perbanas, Karet Kuningan Setiabudi, Jakarta, 12940, Indonesia
}

\begin{tabular}{|c|c|}
\hline \multirow[b]{2}{*}{$\begin{array}{l}\text { Keywords: Credit } \\
\text { Risk, Banking } \\
\text { Performance; } \\
\text { Macroeconomic; } \\
\text { Autoregressive; } \\
\text { Distributed Lag } \\
\\
\text { JEL Classification: } \\
\text { E44, G21, G31 }\end{array}$} & $A B$ \\
\hline & $\begin{array}{l}\text { This study aims to identify factors that can be used as indicators in reducing the incidence of credit } \\
\text { risk in sharia banking and conventional banking. The variables that become observations include } \\
\text { banking performance in each group and macroeconomic performance. The banking performance } \\
\text { variables include credit risk itself as measured by problem financing, growth in financing, growth } \\
\text { in third party funds, and banking size. While macroeconomic variables include national income, } \\
\text { interest rates, and inflation. Autoregressive and distributed lag methods are used to identify which } \\
\text { variables can be used as indicators. The results showed that all identified factors can be an indica- } \\
\text { tor in the process of credit risk control both in sharia banking and conventional banking. Only } \\
\text { credit growth in conventional banking alone can not be used as an indicator of credit risk control. }\end{array}$ \\
\hline & ABSTRAK \\
\hline $\begin{array}{l}\text { Kata Kunci: } \\
\text { Risiko Kredit; } \\
\text { Kinerja Bank; } \\
\text { Makroekonomi; } \\
\text { Autoregressive; } \\
\text { Distributed Lag }\end{array}$ & $\begin{array}{l}\text { Penelitian ini bertujuan mengidentifkasi faktor-faktor yang dapat dijadikan indikator } \\
\text { dalam mengurangi timbulnya risiko kredit pada perbankan syariah dan perbankan } \\
\text { konvensional. Adapun variabel yang menjadi pengamatan meliputi kinerja bank pada } \\
\text { setiap kelompok dan kinerja makroekonomi. Variabel kinerja bank meliputi risiko kredit } \\
\text { itu sendiri yang diukur dengan pembiayaan bermasalah, pertumbuhan pembiayaan, } \\
\text { pertumbuhan dana pihak ketiga, dan ukuran perbankan. Sedangkan variabel } \\
\text { makroekonomi meliputi pendapatan nasional, tingkat suku bunga, dan inflasi. Metode } \\
\text { autoregressive dan distributed lag digunakan untuk mengidentifikasi variabel mana saja } \\
\text { yang dapat dijadikan indikator. Hasil penelitian menunjukkan bahwa semua faktor yang } \\
\text { diidentifikasi dapat menjadi indikator dalam proses pengendalian risiko kredit baik itu } \\
\text { pada perbankan syariah maupun perbankan konvensional. Hanya pertumbuhan kredit } \\
\text { di perbankan konvensional saja yang tidak dapat dijadikan indikator pengendalian } \\
\text { risiko kredit. }\end{array}$ \\
\hline
\end{tabular}

$\triangle$ Corresponding Author:

Muhammad Iqbal: Tel. +62 215252 533; Fax. +62 215228460

Email: iqbal@perbanas.id

ISSN:2443-2687 (Online) ISSN:1410-8089 (Print) 


\section{Jurnal Keuangan dan Perbankan | PERBANKAN}

Vol. 21, No. 3, Juli 2017: 481- 497

Salah satu tolak ukur kesehatan suatu bank dapat dinilai dari lancar atau tidaknya pengembalian pembiayaan atau investasi yang disalurkan. Parameter dalam mengukur pembiayaan bermasalah atau kredit macet dapat dilihat dari rasio non performing loan (NPL) untuk bank konvensional atau non performing financing (NPF) untuk bank syariah. Besarnya rasio NPL atau NPF yang diperbolehkan oleh Bank Indonesia adalah maksimal 5 persen. Jika melebihi 5 persen maka akan memengaruhi penilaian tingkat kesehatan bank yang bersangkutan (Riyadi, 2011).

Setelah krisis moneter yang melanda Indonesia di akhir dekade 90-an, pembiayaan bermasalah perbankan konvensional semakin membaik seperti yang ditunjukkan oleh nilai NPL yang senantiasa menurun. Sedangkan pembiayaan bermasalah untuk bank syariahjuga menunjukkan tren yang stabil pada skala 2-4 persen. Sebagaimana terlihat pada Gambar 1, pembiayaan bermasalah yang menggambarkan risiko pembiayaan pada bank syariah lebih rendah sebelum tahun 2007, tetapi setelahnya menjadi lebih tinggi dari bank konvensional bahkan pada dua tahun terakhir (2014-2015) pergerakannya jauh lebih besar. Hal ini mengindikasikan adanya perbedaan tren antara NPL dan NPF, yang artinya setiap adanya perubahan kondisi mikro dan makroekonomi yang terjadi berbeda dampaknya terhadap risiko pembiayaan di masing-masing kelompok bank.

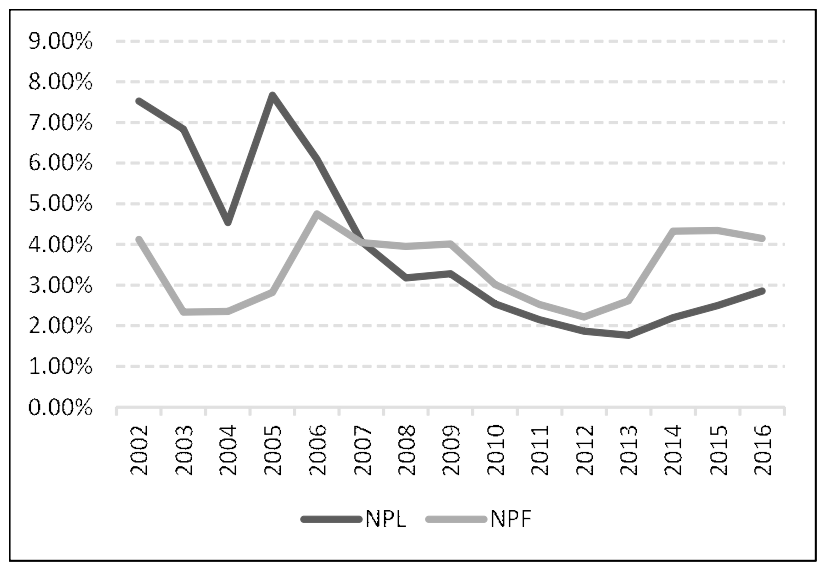

Gambar 1. NPL Bank Konvensional dan NPF Bank Syariah Sumber: Statistika Perbankan Indonesia (2002-2016)
Sebelum tahun 2008, perbankan syariah dengan kondisi-kondisi yang memungkinkan timbulnya pembiayaan bermasalah, seperti tingginya tingkat penyaluran dana kepada masyarakat (financing to deposit ratio atau FDR) dengan kondisi perekonomian yang senantiasa bergejolak, rendahnya alternatif dalam penempatan dana dan beban risiko yang relatif besar dengan penggunaan sistem profit and loss sharing memiliki rasio pembiayaan bermasalah yang lebih kecil dibandingkan dengan perbankan konvensional. Padahal perbankan konvensional lebih memungkinkan untuk meredam timbulnya pembiayaan bermasalah dengan rendahnya tingkat penyaluran dana, berbagai alternatif penempatan dana seperti diperbolehkannya kredit derivatif dan sistem bunga yang dianutnya. Tetapi seiring dengan bertambahnya jumlah bank syariah yang ada, pembiayaan bermasalah di bank syariah tidak sebaik rasio kredit macet di bank konvensional.

NPL dan NPF sebagai salah satu indikator risiko kredit (pembiayaan) bersifat fluktuatif dan tidak pasti oleh karenanya memerlukan perhatian khusus. Semakin rendah NPF akan semakin rendah tingkat pembiayaan bermasalah yang terjadi artinya semakin baik pula kondisi dari bank tersebut. Suatu pembiayaan dinyatakan bermasalah jika bank benar-benar tidak mampu menghadapi risiko yang ditimbulkan oleh pembiayaan tersebut (Mutamimah \& Chasanah, 2012).

Setelah terjadinya beberapa krisis keuangan, ada kesenjangan dalam hal faktor-faktor yang memengaruhi pembiayaan bermasalah antara perbankan syariah dan perbankan konvensional. Dimana tingkat kesehatan perbankan syariah dengan rasio NPF yang lebih tinggi, lebih buruk daripada perbankan konvensional yang memiliki rasio NPL yang lebih rendah. Dan ini artinya bank syariah belum menjalankan fungsi perbankan secara baik terutama dalam kaitannya dengan menjalankan prinsip prudential sebagaimana yang dilakukan oleh perbankan konvensional. 


\section{Perbandingan Pengelolaan Risiko Kredit Perbankan Syariah dan Perbankan Konvensional \\ Muhammad Iqbal}

Kredit macet atau pembiayaan bermasalah yang terjadi di bank sangat dipengaruhi oleh banyak faktor, baik itu dari kinerja internal bank maupun dari eksternal bank seperti kondisi makroekonomi. Dalam jangka pendek ataupun dalam jangka panjang, perubahan variabel makroekonomi sangat berpengaruh terhadap NPF (Nuryartono, Saptono, \& Was'an, 2016). Perlambatan ekonomi diduga kuat menjadi salah satu faktor utama dari tingginya pembiayaan bermasalah pada perbankan syariah (Firmansyah, 2014; Havidz \& Setiawan, 2015) dan kredit macet pada perbankan konvensional (Messai \& Jouini, 2013; Makri, Tsagkanos, \& Bellas, 2014; Rokhim \& Yanti, 2014; Skarica, 2014). Pertumbuhan ekonomi yang sehat mengindikasikan aktivitas ekonomi yang senantiasa bergerak ke arah yang lebih baik. Hal ini akan mendorong pertumbuhan pembiayaan yang akhirnya akan memengaruhi pembiayaan bermasalahnya.

Peningkatan yang cepat dalam portofolio utang memiliki hubungan positif dengan peningkatan rasio NPL di kemudian hari (Jiménez \& Saurina, 2006; Rokhim \& Yanti, 2014). Lebih dari itu, persetujuan kredit selama masa economic booming memberikan probability of default yang tinggi sehingga persetujuan kredit selama masa itu akan mengalami pertumbuhan yang lambat. Pada masa economic booming kebutuhan akan jaminan diperlonggar, dan sebaliknya ketika resesi, ditemukan adanya suatu penyimpangan standar kredit selama masa ekspansi (Jiménez \& Saurina, 2006).

Borio, Furfine, \& Lowe (2001) menjelaskan bahwa dimasa economic booming, ketika terjadi percepatan kredit atau pembiayaan, maka akan memicu timbulnya pembiayaan bermasalah pada periode yang akan datang. Sedangkan selama periode resesi, ketika bank membatasi pertumbuhan kredit dengan jalan lebih berhati-hati dalam menyalurkan pembiayaan, yang dalam hal ini erat kaitan dengan mutu peminjam dan kondisi-kondisi pinjaman. Oleh karena itu, perhatian pengawasan perbankan perlu dilakukan dengan sebaik-baiknya, sebagaimana penjelasan procyclicality sebagai bekas kontribusi risiko kredit, sebagai lawan perilaku bekas pos risiko kredit (non performing loans), yang meningkat selama resesi dan menurun pada masa yang baik.

Selain dari itu, pertumbuhan aset diduga kuat ikut mendorong peningkatan kredit bermasalah (Jiménez \& Saurina, 2006; Chaibi, 2016). Tumbuhnya aset perbankan syariah, ikut meningkatkan pembiayaan bermasalahnya. Padahal dalam kondisi market share yang relatif kecil perbankan syariah mampu mempertahankan kinerjanya dalam menjaga tingkat kesehatannya. Dalam beberapa periode pengamatan, ukuran perusahaan yang direpresentasikan oleh pertumbuhan aset ikut mendorong tingginya risiko kredit bank umum di Indonesia (Barus \& Erick, 2017). Meskipun demikian, tidak selalu ukuran perusahaan menyebabkan timbulnya risiko pembiayaan (Firmansyah, 2014; Riyadi, Iqbal, \& Lauren, 2015).

Tingkat suku bunga yang berlaku menjadi salah satu indikator makroekonomi. Tingginya tingkat suku bunga akan mendorong tingginya pembiayaan bermasalah (Messai \& Jouini, 2013; Vatansever \& Hepsen, 2015; Barus \& Erick, 2017). Tingginya tingkat suku akan berdampak menurunkan investasi dan aktivitas bisnis di sektor riil. Selain itu, tingkat inflasi juga akan bertambah tinggi dan akan menurunkan daya beli masyarakat sehingga keuntungan yang diperoleh pelaku usaha di sektor riil menjadi berkurang. Hal ini tentunya mengurangi kemampuan pelaku usaha untuk memenuhi kewajiban-kewajibannya kepada dunia perbankan, yang pada akhirnya menyebabkan tingginya pembiayaan bermasalah. Sebaliknya, jika tingkat suku bunga rendah, maka aktivitas bisnis meningkat, inflasi rendah, dan daya beli meningkat sehingga keuntungan sektor riil meningkat dan kemampuan membayar kewajiban kepada bank juga ikut meningkat. Hal ini tentunya mengurangi pembiayaan bermasalah pada sektor perbankan.

Salah satu instrumen moneter yang digunakan Bank Indonesia adalah tingkat suku bunga SBI 


\section{Jurnal Keuangan dan Perbankan | PERBANKAN}

Vol. 21, No. 3, Juli 2017: 481- 497

(Setifikat Bank Indonesia) bagi perbankan konvensional dan SWBI (Sertifikat Wadi'ah Bank Indonesia) bagi perbankan syariah. Meskipun ada perbedaan instrumen moneter antara bank konvensional dan bank syariah, kebijakan moneter melalui SBI lebih berdampak kepada perbankan syariah. Hartono (2006) menyatakan bahwa suku bunga SBI dan dana pihak ketiga (DPK) Bank Muamalat Indonesia (BMI), sebagai bank syariah tertua di Indonesia, berpengaruh terhadap NPF BMI. Setiap peningkatan Suku Bunga SBI akan mengakibatkan kenaikan NPF BMI dan setiap peningkatan DPK BMI akan mengakibatkan penurunan NPF BMI.

Seiring dengan pertumbuhan ekonomi dan tingkat suku bunga yang kompetitif, perbankan syariah dengan pertumbuhan pembiayaan yang sangat tinggi memiliki risiko kredit atau rasio pembiayaan bermasalah yang relatif lebih kecil dibandingkan dengan perbankan konvensional yang memiliki tingkat pertumbuhan kredit yang relatif lebih kecil. Padahal pertumbuhan pembiayaan yang tinggi di suatu bank akan mendorong tingginya rasio pembiayaan bermasalah pada bank tersebut.

Selain pertumbuhan ekonomi dan tingkat suku bunga, inflasi sebagai indikator makroekonomi diduga kuat ikut memengaruhi risiko kredit perbankan. Inflasi menyebabkan melemahnya kekuatan ekonomi masyarakat sehingga masyarakat semakin tidak mampu membayar kewajiban utangnya. Sebagaimana yang diungkapkan oleh Škarica (2013), bahwa tingginya tingkat inflasi menyebabkan rasio NPL tumbuh. Kebijakan moneter ekspansif diharapkan akan meningkatkan PDB dan permintaan agregat yang juga ikut meningkatkan laju inflasi secara signifikan. Pada akhirnya menyebabkan tumbuhnya rasio NPL. Lain halnya dengan temuan Firmansyah (2014) yang menyatakan bahwa inflasi berpengaruh negatif terhadap pembiayaan bermasalah. Saat daya beli masyarakat turun, mereka tidak mengurangi kewajibannya dalam melunasi utangnya di bank. Inflasi tidak merusak kualitas pembiayaan masyarakat. Dari sini menunjukkan bahwa bank membantu masyarakat yang membutuhkan modal usaha. Sama halnya dengan yang diungkapkan oleh Barus \& Erick (2017) bahwa semakin tinggi tingkat inflasi maka akan semakin menurunkan NPL. Meskipun demikian, tidak semua menyatakan hal serupa. Havidz \& Setiawan (2015) serta Laryea, Ntow-Gyamfi, \& Alu (2016) menemukan bahwa tinggi rendahnya inflasi tidak memberikan dampak berarti terhadap risiko kredit yang direpresentasikan oleh NPL.

Teridentifikasinya faktor-faktor yang memengaruhi risiko kredit di industri perbankan Indonesia diharapkan menjadi salah satu instrumen dalam mengukur timbulnya pembiayaan bermasalah. Baik faktor kinerja bank maupun makroekonomi seperti pembiayaan bermasalah, pertumbuhan pembiayaan, pertumbuhan DPK, ukuran bank, pendapatan nasional, tingkat suku bunga, dan inflasi menjadi indikator dalam pengelolaan risiko kredit pada masing-masing kelompok bank. Bank syariah dan bank konvensional memiliki perubahan tingkat risiko kredit yang berubah seiring dengan perubahan kondisi ekonomi dan perkembangan dunia perbankan sehingga penanganan risiko kredit menjadi hal menarik yang perlu dicermati sebagai salah satu strategi industri perbankan dalam menjaga tingkat kesehatannya dan juga meningkatkan kinerjanya.

\section{METODE}

Penelitian ini mengunakan metode kuantitatif dengan pendekatan asosiatif kausal (Sugiyono, 2014). Selain itu, penelitian juga menggunakan pendekatan komparatif guna mendapatkan hasil perbandingan antara faktor-faktor yang memengaruhi pembiayaan bermasalah pada perbankan syariah dan konvensional. Metode penelitian komparatif bersifat ex post facto, artinya data 


\section{Perbandingan Pengelolaan Risiko Kredit Perbankan Syariah dan Perbankan Konvensional \\ Muhammad Iqbal}

dikumpulkan setelah semua kejadian yang dikumpulkan telah selesai berlangsung. Pengujian hipotesis dilakukan sebagai suatu cara mengidentifikasi faktor-faktor yang memengaruhi pembiayaan bermasalah.

Populasi mencakup seluruh jenis bank yang ada di Indonesia, baik itu bank umum maupun bank perkreditan rakyat. Sedangkan sampel yang diambil dalam penelitian ini hanya sebatas bank umum saja, baikitu bank umum konvensional maupun bank umum syariah. Dimana bank umum konvensional meliputi bank devisa maupun non devisa, sedangkan bank umum syariah meliputi bank umum syariah dan unit usaha syariah. Seluruh data penelitian menggunakan data sekunder yang diperoleh dari statistika perbankan Indonesia, statistika perbankan syariah, dan indikator moneter perbankan yang dikeluarkan oleh Bank Indonesia (BI) dan Otoritas Jasa Keuangan (OJK). Data bersifat time series dengan periode pengamatan dari triwulan pertama tahun 2001 sampai dengan triwulan terakhir tahun 2016.

Metode analisis yang digunakan adalah analisis regresi dengan pendekatan Autoregressive and Distributed Lag (ADL). Model ini dipilih atas dasar kepentingan penelitian yang ingin mengidentifikasi pengaruh variabel bebas dari beberapa periode sebelumnya terhadap variabel terikatnya. Pada model autoregressive dan distributed lag hal ini sangat dimungkinkan jika dibandingkan dengan model regresi lainnya seperti regresi linier berganda (Gujarati \& Porter, 2008).

Ada beberapa pendekatan dalam mengestimasi model autoregressive dan distributed lag, seperti estimasi Ad Hoc, pendekatan Koyck, dan pendekatan Almon. Adapun pendekatan yang digunakan pada penelitian ini adalah pendekatan Almon atau polynomial distributed lag (PDL). Pendekatan Almon dilakukan dengan asumsi bahwa koefisien-koefisien regresi mengikuti sebuah pola yang bersiklus. Almon mengasumsikan bahwa koefisien regresi bisa dikira-kira oleh polynomial dengan derajat yang sesuai dari panjangnya lag. Pendekatan Almon diestimasi menggunakan prosedur ordinary least squared (OLS) yang biasa, oleh karena itu perlu dipenuhi pula syarat-syarat yang terdapat dalam model OLS, yaitu syarat BLUE (best linear unbiased estimator) atau terbebas dari pelanggaran asumsi-asumsi dasar (Almon, 1965). Masalah pelanggaran asumsi klasik yang akan diuji dalam penelitian ini adalah autokorelasi, heteroskedastisitas, dan normalitas. Sedangkan untuk asumsi multikolinieritas tidak dilakukan pengujian karena hal ini sudah pasti terjadi, namun demikian masalah yang ditimbulkan tidak berdampak serius terhadap model regresinya (Gujarati \& Porter, 2008). Tahap akhir analisis adalah uji kelayakan model dengan uji $\mathrm{F}$ dan koefisien determinasi, serta uji koefisien regresi atau uji-t.

Pemilihan variabel-variabel penelitian mengacu kepada penelitian yang pernah dilakukan sebelumnya seperti penelitian Gerlach, Peng, \& Shu (2003) dan penelitian Jiménez \& Saurina (2006) dan penelitian-penelitian lainnya yang serupa. Penelitian yang akan dilakukan pada setiap kelompok perbankan meliputi penilaian atas indikator-indikator utama perbankan nasional, seperti rasio NPL dan NPF, pertumbuhan kredit atau pembiayaan, pertumbuhan dana pihak ketiga (DPK), dan aset dari masing-masing kelompok bank. Selain itu ada pula indikator-indikator makroekonomi juga dimasukkan dalam penelitian ini, yaitu pendapatan nasional atau produk domestik bruto (PDB), tingkat suku bunga, dan tingkat inflasi.

Riyadi (2011) menjelaskan bahwa rasio NPL atau NPF ini terbagi menjadi 2, NPL gross dan NPL nett. NPL gross adalah perbandingan antara jumlah kredit yang diberikan dengan tingkat kolektibilitas 3-5 dibandingkan dengan total kredit yang diberikan oleh bank. NPL nett adalah perbandingan antara jumlah kredit yang diberikan dengan tingkat kolektibilitas 3-5 dikurangi PPAP (penyisihan penghapusan aktiva produktif) kolektibilitas 3-5. Rasio NPL dan NPF yang digunakan dalam 


\section{Jurnal Keuangan dan Perbankan | PERBANKAN}

Vol. 21, No. 3, Juli 2017: 481- 497

penelitian ini adalah yang gross. Pertumbuhan kredit atau pembiayaan dan DPK diukur dengan cara yang sama, yaitu selisih nilai periode berjalan dengan periode sebelumnya dibagi dengan nilai di periode sebelumnya. Pengukuran PDB yang digunakan adalah atas dasar harga konstan, tingkat suku bunga mengacu pada BI rate, sedangkan tingkat inflasi diukur dari selisih nilai indeks harga konsumen (IHK) periode berjalan dengan periode sebelumnya dibagi dengan nilai di periode sebelumnya.

Setelah mengidentifikasi faktor-faktor yang memengaruhi pembiayaan bermasalah di setiap kelompok perbankan, peneliti juga ingin melihat apakah ada perbedaan faktor-faktor yang menyebabkan pembiayaan bermasalah di perbankan konvensional dan perbankan syariah dengan cara melakukan perbandingan langsung antara kelompok bank tersebut. Setelah itu, peneliti mencoba mengidentifikasi sejauh mana variabel-variabel bebas tadi memengaruhi masing-masing kelompok perbankan.

Model autoregressive dan distributed lag yang dibuat terbagi menjadi 2, yaitu model autoregressive dan distributed lag untuk perbankan syariah dan model autoregressive dan distributed lag untuk perbankan konvensional. Model autoregressive dan distributed lag untuk perbankan syariah adalah sebagai berikut:

$N P F_{t}=\beta_{0}+\sum_{i=1}^{k} \beta_{1 i} N P F_{t-i}+\sum_{i=0}^{k} \beta_{2 i} G F I N_{t-i}+\sum_{i=0}^{k} \beta_{3 i} D P K S_{t-i}+\sum_{i=0}^{k} \beta_{4 i} \operatorname{SIZES}_{t-i}$ $+\sum_{i=0}^{k} \beta_{5 i} G D P_{t-i}+\sum_{i=0}^{k} \beta_{6 i} R A T E_{t-i}+\sum_{i=0}^{k} \beta_{7 i} I N F_{t-i}+u_{t}$

Sedangkan model autoregressive dan distributed lag untuk perbankan konvensional adalah sebagai berikut:

$N P L_{t}=\alpha_{0}+\sum_{i=1}^{k} \alpha_{1 i} N P L_{t-i}+\sum_{i=0}^{k} \alpha_{2 i} G L O A N_{t-i}+\sum_{i=0}^{k} \alpha_{3 i} G D P K K_{t-i}+\sum_{i=0}^{k} \alpha_{4 i} S I Z E K_{t-i}$ $+\sum_{i=0}^{k} \alpha_{5 i} G D P_{t-i}+\sum_{i=0}^{k} \alpha_{6 i} R A T E_{t-i} \alpha_{6}+\sum_{i=0}^{k} \alpha_{7 i} I N F_{t-i}+\varepsilon_{t}$
Keterangan:

NPF : rasio NPF (non performing financing)

NPL : rasio NPL (non performing loan)

GFIN : pertumbuhan pembiayaan perbankan syariah

GLOAN : pertumbuhan kredit perbankan konvensional

GDPKS : pertumbuhan dana pihak ketiga perbankan syariah

GDPKK : pertumbuhan dana pihak ketiga perbankan konvensional

SIZES : aset perbankan syariah

SIZEK : aset perbankan konvensional

GDP : produk domestik bruto

RATE : tingkat suku bunga

INF : tingkat inflasi

Pembentukan model penelitian di atas tentunya akan mengalami penyesuaian, seberapa besar lag yang terbentuk dari masing-masing variabel penelitian. Hal ini disesuaikan dengan kebutuhan analisis dan karakteristik data perbankan nasional.

\section{HASIL}

Penelitian ini ingin melihat risiko kredit yang dihadapi oleh dunia perbankan di Indonesia, baik itu pada industri perbankan konvensional maupun industri perbankan syariah. Identifikasi terhadap faktor-faktor yang memengaruhi risiko kredit tersebut diharapkan dapat menjadi kontrol terhadap pengelolaan kredit macet atau pembiayaan bermasalah yang akan dihadapi dikemudian hari. Perilaku kredit macet yang direpresentasikan oleh NPL pada bank konvensional dan NPF pada bank syariah di masa yang akan datang merupakan dampak dari macetnya kredit di periode sebelumnya (Jiménez \& Saurina, 2006). Begitu pula dengan faktor-faktor kondisi perbankan dan kondisi eko- 


\section{Perbandingan Pengelolaan Risiko Kredit Perbankan Syariah dan Perbankan Konvensional}

Muhammad Iqbal

nomi secara umum yang memiliki kesenjangan waktu dalam memengaruhi kredit macet. Atas kondisi ini, metode regresi linier dengan pendekatan ordinary least squared sangat mungkin menyebabkan intepretasi yang salah akibat adanya spurious regression karena jenis data yang bersifat time series (Gujarati \& Porter, 2008). Pengujian terhadap stasioneritas data pada setiap variabel penelitian akan menghindari jebakan spurious regression. Hasil uji stasioneritas data penelitian disajikan pada Tabel 1.

Hasil uji stasioneritas sebagaimana tersaji pada Tabel 1 menunjukkan bahwa tidak semua variabel penelitian stasioner pada level. Beberapa variabel dengan nilai probability Phillips-Perron tstatistic nilainya masih lebih besar dari tingkat kesalahan $(\alpha=0,05)$ yang mengindikasikan tidak stasioner pada level (lihat kolom level). Barulah pada first differencing semua variabel telah stasioner.
Hal ini ditunjukkan oleh nilai probability PhillipsPerron $t$-statistic yang lebih kecil dari $\alpha=0,05$ (lihat kolom first deffrent). Hal ini mengindikasikan bahwa variabel-variabel bebas memiliki kesenjangan dalam memengaruhi kredit macet, begitu pula dengan variabel kredit macet itu sendiri.

Hasil uji stasioneritas mengindikasikan bahwa regresi yang dibentuk tanpa disertai interval waktu dari variabel-variabelnya akan menimbulkan spurious regression. Untuk itu dibutuhkan differencing (pembedaan) atau lag waktu dalam membuat persamaan regresinya. Penggunaan model autoregressive and distributed lag (ADL) diharapkan menjadi salah satu cara menyiasati spurious regression, walaupun metode autoregressive dan distributed lag tidak dikhususkan untuk tujuan tersebut. Salah satu indikator terjadinya spurious regression adalah terjadinya autokorelasi pada model regresi. Hasil regresi linier dengan OLS menunjuk-

Tabel 1. Uji Stasioneritas dengan Phillips-Perron

\begin{tabular}{lcccc}
\hline \multirow{2}{*}{ Variabel } & \multicolumn{2}{c}{ Level } & & \multicolumn{2}{c}{ First Deffrent } \\
\cline { 2 - 4 } & $\boldsymbol{t}$-Stat & Prob. & $\boldsymbol{t}$-Stat & 0,0000 \\
NPF & $-5,3032$ & 0,0000 & $-7,4440$ & 0,0000 \\
NPL & $-4,9985$ & 0,0001 & $-5,9749$ & 0,0001 \\
GFIN & $-4,2862$ & 0,0011 & $-24,7619$ & 0,0001 \\
GLOAN & $-7,4685$ & 0,0000 & $-41,4500$ & 0,0001 \\
GDPKS & $-6,8788$ & 0,0000 & $-50,7775$ & 0,0001 \\
GDPKK & $-11,1816$ & 0,0000 & $-46,1663$ & 0,0012 \\
SIZES & 4,9216 & 1,0000 & $-4,2493$ & 0,0000 \\
SIZEK & 5,4325 & 1,0000 & $-6,9326$ & 0,0000 \\
GDP & 3,7010 & 1,0000 & $-11,0467$ & 0,0014 \\
RATE & $-1,9796$ & 0,2950 & $-4,2023$ & 0,0000 \\
INF & $-2,7026$ & 0,0792 & $-7,3312$ & \\
\hline
\end{tabular}

Tabel 2.Uji Autokorelasi: Breusch-Godfrey

\begin{tabular}{lcccc}
\hline \multicolumn{1}{c}{ Model } & F-statistic & Prob. F & $\begin{array}{c}\text { Obs* } \\
\text { R-squared }\end{array}$ & $\begin{array}{c}\text { Prob. } \\
\text { Chi-squared }\end{array}$ \\
\hline OLS & & & & \\
$\quad$ Perbankan Syariah & 14,939 & 0,0000 & 22,529 & 0,0000 \\
$\quad$ Perbankan Konvensional & 9,4415 & 0,0003 & 16,357 & 0,0003 \\
ADL & & & & 0,5475 \\
$\quad$ Perbankan Syariah & 0,2766 & 0,7605 & 1,2047 & 0,1729 \\
$\quad$ Perbankan Konvensional & 1,1493 & 0,3279 & 3,5095 & \\
\hline
\end{tabular}




\section{Jurnal Keuangan dan Perbankan | PERBANKAN}

Vol. 21, No. 3, Juli 2017: 481- 497

kan hal tersebut, sedangkan hasil regresi dengan metode ADL tidak demikian. Tabel 2 menunjukkan adanya autokorelasi pada model regresi OLS di perbankan syariah dan perbankan konvensional. Hal ini ditunjukkan dari nilai probabilitas LM test (Prob. F) yang lebih kecil dari 0,05. Sedangkan pada model ADL pada perbankan syariah dan konvensional nilai probabilitas LM test lebih besar dari $\alpha=0,05$.

Selain adanya masalah autokorelasi pada model regresi, masalah heteroskedastisitas juga menjadi perhatian dalam pembentukan model. Hasil pengujian terhadap metode autoregressive dan distributed lag pada perbankan syariah dan konvensional dapat dilihat pada Tabel3. Nilai probabilitas F-statistic pada Uji Glejser pada kedua model lebih besar dari $\alpha=0,05$ yang artinya tidak terjadi heterokedastisitas.

Hasil uji normalitas dengan uji Jarque-Bera disajikan pada Tabel 4, yang menunjukkan bahwa residual regresi dari kedua model berbeda. Untuk model regresi pada perbankan syariah residual terdistribusi normal, ditunjukkan oleh hasil probabilitas JB yang lebih besar dari $\alpha=0,05$. Sedangkan pada model regresi perbankan konvensional hasil uji JB menunjukkan hasil yang sebaliknya. Meskipun demikian, sesuai dengan teorema limit terpusat data yang berukuran besar masih dapat dianggap terdistribusi normal (Gujarati \& Porter, 2008).
Metode ADL yang digunakan untuk mengestimasi faktor-faktor yang memengaruhi pembiayaan bermasalah pada perbankan syariah dan perbankan konvensional menggunakan pendekatan Almon (1965) atau yang biasa disebut dengan polynomial distributed lag. Model ADL perbankan syariah yang ditampilkan pada Tabel 5 telah memenuhi uji kelayakan model. Sebagaimana terlihat dari nilai probabilitas F statistik yang kurang dari $\alpha=0,05$. Nilai koefisien determinasi (R-squared) yang tinggi menunjukkan bahwa persentase variabel-variabel bebas penduga variabel terikat NPF yang ada pada model telah mencapai $92,28 \%$. Nilai DW statistik juga telah mendekati angka 2 sebagai indikasi bahwa model telah terbebas dari masalah autokorelasi. Hal ini juga memperkuat hasil uji autokorelasi dengan pendekatan LM test seperti yang telah sajikan pada Tabel 2 .

Hasil uji t pada model ADL perbankan syariah, secara umum menunjukkan bahwa semua variabel bebas memiliki pengaruh yang signifikan terhadap pembiayaan bermasalah di bank syariah. Pembiayaan bermasalah (NPF) di masa yang lalu secara kontinu memiliki pengaruh yang signifikan secara berturut-turut di 3 periode triwulan ke belakang. Nilai NPF(-1), NPF(-2) dan NPF(-3) semuanya signifikan sampai dengan $\alpha=0,01$. Sedangkan untuk pertumbuhan pembiayaan yang berpengaruh signifikan hanya pada periode berjalan (GFIN) dan 6 bulan ke belakang (GFIN(-2)). Nilai

Tabel 3.Uji Heterokedastisitas: Glejser Test

\begin{tabular}{lcccc}
\hline \multicolumn{1}{c}{ Model } & F-statistic & Prob. $\boldsymbol{F}$ & Obs* $\boldsymbol{R}$-squared & Prob. Chi-squared \\
\hline Perbankan Syariah & 1,2913 & 0,2467 & 34,3131 & 0,2685 \\
Perbankan Konvensional & 1,4784 & 0,1454 & 25,8731 & 0,1700 \\
\hline
\end{tabular}

Tabel 4.Uji Normalitas: Jarque-Bera Test

\begin{tabular}{lcc}
\hline \multicolumn{1}{c}{ Model } & JB-statistic & Prob. JB \\
\hline Perbankan Syariah & 1,2152 & 0,5446 \\
Perbankan Konvensional & 30,739 & 0,0000 \\
\hline
\end{tabular}




\section{Perbandingan Pengelolaan Risiko Kredit Perbankan Syariah dan Perbankan Konvensional}

Muhammad Iqbal

probabilitas untuk pertumbuhan pembiayaan 3 bulan ke belakang (GFIN(-1)) lebih besar dari tingkat kesalahan 10 persen $(\alpha=0,1)$ sehingga pertumbuhan pembiayaan 3 bulan ke belakang tidak berpengaruh signifikan terhadap pembiayaan bermasalah di periode berjalan.

Dua variabel kinerja bank syariah lainnya, yaitu pertumbuhan dana pihak ketiga (GDPKS) dan aset (SIZES) memiliki pengaruh yang juga berbeda-beda periodenya. Pada periode berjalan, pertumbuhan dana pihak ketiga dan aset tidak berpengaruh signifikan terhadap pembiayaan bermasalah. Hal ini ditunjukkan oleh nilai probabilitas keduanya yang lebih besar dari $\alpha=0,10$. Pertumbuhan dana pihak ketiga berpengaruh signifikan pada 9 bulan dan setahun ke belakang dengan tingkat signifikansi yang berbeda-beda. GDPKS(3) signifikan pada alpha 10 persen, sedangkan GDPKS(-4) signifikan pada alpha 5 persen. Sedangkan untuk aset perbankan syariah pada 3 bulan ke belakang (SIZES(-1)) dan setahun yang lalu (SIZES $(-4)$ ) berpengaruh signifikan terhadap pembiayaan bermasalah pada tingkat signifikansi yang sama, yaitu 5 persen.

Variabel-variabel makroekonomi memiliki pengaruh yang signifikan terhadap pembiayaan bermasalah di bank syariah pada periode yang berbeda-beda. Pendapatan nasional memiliki pengaruh yang signifikan hampir setiap 3 bulannya dalam setahun belakangan. Pendapatan nasional saat ini (GDP) memengaruhi pembiayaan bermasalah pada periode yang sama pada tingkat signifikansi 5\%. Sedangkan pendapatan nasional di 3 bulan (GDP(1)), 9 bulan (GDP(-3)), dan setahun (GDP(-4)) ke belakang berpengaruh signifikan pada tingkat signifikansi $10 \%$. Tingkat suku bunga berpengaruh signifikan terhadap pembiayaan bermasalah di bank syariah pada 6 bulan (RATE(-2)) dan 9 bulan (RATE(-3)) ke belakang pada tingkat signifikansi yang sama, yaitu 5 persen. Sedangkan inflasi berpengaruh signifikan terhadap pembiayaan bermasalah di bank syariah pada 3 bulan $(\operatorname{INF}(-1)), 6$ bulan (INF(-2)), dan 9 bulan (INF(-3)) ke belakang dengan tingkat signifikansi secara berturut-turut 10 persen, 5 persen, dan 1 persen.
Model ADL perbankan syariah dan perbankan konvensional yang terbentuk sudah merupakan seleksi dari beberapa alternatif model ADL dengan mempertimbangkan kriteria Akaike Info Criterion (AIC). Jumlah lag maksimum model tidak lebih dari 4 atau setahun ke belakang. Sebagaimana yang terlihat dalam Tabel 5, model ADL perbankan syariah yang terbentuk adalah $\operatorname{ADL}(3,2,4,4,4$, $4,3)$. Sedangkan model ADL perbankan konvensional (Tabel 6) adalah ADL (1, 1, 3, 4, 1, 4, 0).

Model ADL perbankan konvensional seperti pada Tabel 6 telah juga telah memenuhi uji kelayakan model. Nilai probabilitas F statistik yang kurang dari $\alpha=0,05$. Nilai koefisien determinasinya (R-squared) juga tinggi. Artinya, persentase variabel-variabel bebas penduga variabel terikat NPL yang ada pada model mencapai 97,75 persen. Nilai ini lebih besar dari model ADL perbankan syariah. Model ADL perbankan konvensional juga telah terbebas dari masalah autokorelasi yang ditunjukkan oleh nilai DW statistik yang telah mendekati angka 2. Sejalan dengan hasil uji autokorelasi dengan LM test (Tabel 2).

Hasil uji-t pada model ADL perbankan konvensional sangat jauh berbeda dengan model ADL perbankan syariah. Jika pada model perbankan syariah lebih banyak variabel yang signifikan memengaruhi pembiayaan bermasalah, maka pada model perbankan konvensional sebaliknya, lebih banyak variabel yang tidak berpengaruh signifikan terhadap kredit bermasalahnya. Pada model ADL perbankan konvensional tidak semua variabel berpengaruh signifikan terhadap kredit bermasalahnya. Pertumbuhan kredit perbankan konvensional tidak berpengaruh signifikan sama sekali terhadap kredit bermasalahnya. Sedangkan variabel kinerja perbankan konvensional yang berpengaruh signifikan adalah kredit bermasalah itu sendiri di 3 bulan yang lalu (NPL(-1)), pertumbuhan dana pihak ketiga di 9 bulan yang lalu (GDPKK(3)) dan aset di setahun ke belakang (SIZEK(-4)). Tingkat signifikansi NPL(-1) sampai dengan 1 persen, sedangkan GDPKK(-3) dan SIZEK(-4) sama-sama signifikan pada level 5 persen. 
Tabel 5. Model Autoregressive dan Distributed Lag Perbankan Syariah

\begin{tabular}{|c|c|c|c|}
\hline Variabel & Koefisien & Prob. t-Statistik & Signifikansi \\
\hline $\mathrm{NPF}(-1)$ & 0,5764 & 0,0002 & Signifikan \\
\hline $\mathrm{NPF}(-2)$ & $-0,3618$ & 0,0295 & Signifikan \\
\hline $\operatorname{NPF}(-3)$ & 0,3516 & 0,0082 & Signifikan \\
\hline GFIN & $-0,0966$ & 0,0072 & Signifikan \\
\hline GFIN(-1) & 0,0360 & 0,1421 & Tidak Signifikan \\
\hline GFIN(-2) & $-0,0407$ & 0,0860 & Signifikan \\
\hline GDPKS & $-0,0292$ & 0,1693 & Tidak Signifikan \\
\hline GDPKS(-1) & $-0,0217$ & 0,3172 & Tidak Signifikan \\
\hline GDPKS(-2) & 0,0326 & 0,1270 & Tidak Signifikan \\
\hline GDPKS(-3) & 0,0382 & 0,0760 & Signifikan \\
\hline GDPKS(-4) & $-0,0376$ & 0,0482 & Signifikan \\
\hline SIZES & 0,2888 & 0,1372 & Tidak Signifikan \\
\hline SIZES(-1) & $-0,5963$ & 0,0448 & Signifikan \\
\hline SIZES(-2) & 0,1045 & 0,6852 & Tidak Signifikan \\
\hline SIZES(-3) & $-0,1198$ & 0,6391 & Tidak Signifikan \\
\hline SIZES(-4) & 0,3990 & 0,0412 & Signifikan \\
\hline GDP & 0,5926 & 0,0427 & Signifikan \\
\hline GDP(-1) & $-0,2160$ & 0,0943 & Signifikan \\
\hline $\operatorname{GDP}(-2)$ & 0,1964 & 0,1110 & Tidak Signifikan \\
\hline $\operatorname{GDP}(-3)$ & $-0,2175$ & 0,0686 & Signifikan \\
\hline $\operatorname{GDP}(-4)$ & $-0,4528$ & 0,0962 & Signifikan \\
\hline RATE & $-0,1955$ & 0,2360 & Tidak Signifikan \\
\hline RATE(-1) & $-0,0735$ & 0,7457 & Tidak Signifikan \\
\hline RATE(-2) & 0,5428 & 0,0295 & Signifikan \\
\hline $\operatorname{RATE}(-3)$ & $-0,5638$ & 0,0281 & Signifikan \\
\hline $\operatorname{RATE}(-4)$ & 0,1462 & 0,2879 & Tidak Signifikan \\
\hline INF & $-0,0132$ & 0,7946 & Tidak Signifikan \\
\hline $\operatorname{INF}(-1)$ & 0,0809 & 0,0990 & Signifikan \\
\hline $\operatorname{INF}(-2)$ & $-0,1202$ & 0,0198 & Signifikan \\
\hline $\operatorname{INF}(-3)$ & 0,1461 & 0,0031 & Signifikan \\
\hline $\mathrm{C}$ & 0,0656 & 0,0626 & Signifikan \\
\hline \multicolumn{4}{|l|}{ R-squared $=0,9228$} \\
\hline \multicolumn{4}{|l|}{ F-statistic $=11,5560$} \\
\hline \multicolumn{4}{|c|}{$\operatorname{Prob}($ F-statistic $)=0,00000$} \\
\hline \multicolumn{4}{|c|}{ Durbin-Watson stat $=2,1700$} \\
\hline
\end{tabular}


Ketiga variabel makroekonomi memengaruhi kredit bermasalah di bank konvensional secara signifikan dengan periode yang berbeda-beda. Pendapatan nasional di 3 bulan yang lampau (GDP(1)) berpengaruh signifikan terhadap kredit bermasalah sampai dengan tingkat signifikansi 1 persen. Suku bunga berpengaruh signifikan terhadap kredit bermasalah pada periode berjalan (RATE) dan setahun yang lalu (RATE(-4)). Sedangkan tingkat inflasi berpengaruh signifikan terhadap kredit bermasalah di bank konvensional pada periode ber- jalan (INF). Tingkat signifikansi RATE sebesar 5 persen, sedangkan RATE(-4) dan INF sama-sama 10 persen.

\section{PEMBAHASAN}

Besarnya pembiayaan bermasalah yang ditimbulkan pada perbankan syariah dan kredit bermasalah pada perbankan konvensional mencerminkan pengelolaan risiko kredit yang dilakukan oleh masing-masing kelompok bank. Identifikasi

Tabel 6. Model Autoregressive dan Distributed

\begin{tabular}{lccl}
\hline \multicolumn{1}{c}{ Variabel } & Koefisien & Prob. t-Statistik & \multicolumn{1}{c}{ Signifikansi } \\
\hline NPL(-1) & 0,6371 & 0,0000 & Signifikan \\
GLOAN & 0,0026 & 0,9436 & Tidak Signifikan \\
GLOAN(-1) & $-0,0564$ & 0,1536 & Tidak Signifikan \\
GDPKK & 0,0991 & 0,1446 & Tidak Signifikan \\
GDPKK(-1) & 0,0603 & 0,3379 & Tidak Signifikan \\
GDPKK(-2) & 0,0434 & 0,5178 & Tidak Signifikan \\
GDPKK(-3) & 0,1636 & 0,0224 & Signifikan \\
SIZEK & $-0,0064$ & 0,7227 & Tidak Signifikan \\
SIZEK(-1) & 0,0121 & 0,6073 & Tidak Signifikan \\
SIZEK(-2) & $-0,0053$ & 0,8122 & Tidak Signifikan \\
SIZEK(-3) & $-0,0395$ & 0,1040 & Tidak Signifikan \\
SIZEK(-4) & 0,0586 & 0,0106 & Signifikan \\
GDP & 0,0604 & 0,5161 & Tidak Signifikan \\
GDP(-1) & $-0,3247$ & 0,0019 & Signifikan \\
RATE & 0,3849 & 0,0458 & Signifikan \\
RATE(-1) & $-0,0281$ & 0,8996 & Tidak Signifikan \\
RATE(-2) & $-0,1224$ & 0,5972 & Tidak Signifikan \\
RATE(-3) & 0,1523 & 0,5122 & Tidak Signifikan \\
RATE(-4) & $-0,2673$ & 0,0537 & Signifikan \\
INF & $-0,1118$ & 0,0754 & Signifikan \\
C & 0,1062 & 0,0001 & Signifikan \\
\hline R-squared= 0,9775 & & & \\
F-statistic= 84,8251 & & & \\
Prob(F-statistic)=0,0000 & & & \\
Durbin-Watson stat= 1,8551 & & & \\
\hline
\end{tabular}




\section{Jurnal Keuangan dan Perbankan | PERBANKAN}

Vol. 21, No. 3, Juli 2017: 481- 497

terhadap faktor-faktor yang memengaruhi pembiayaan bermasalah diharapkan dapat menjadi bentuk pengendalian risiko kredit terhadap faktorfaktor yang menimbulkan potensi risiko kredit di masa depan. Faktor-faktor kinerja bank dan makroekonomi mana saja dan pada periode kapan saja yang memicu timbulnya risiko kredit menjadi indikator kuat dalam upaya pengelolaan dan pengendalian risiko kredit. Pembahasan terhadap faktorfaktor timbulnya risiko kredit yang diukur dengan pembiayaan bermasalah akan dijabarkan satu persatu. Diawali dari kinerja bank yang meliputi pembiayaan bermasalah di masa lalu, pertumbuhan kredit, pertumbuhan DPK, dan aset masing-masing kelompok bank. Setelah itu dilanjutkan dengan pembahasan variabel makroekonomi yang meliputi pendapatan nasional, tingkat suku bunga, dan tingkat inflasi.

Baik pada perbankan syariah maupun perbankan konvensional, pembiayaan bermasalah satu periode sebelumnya (3 bulan yang lalu) berpengaruh signifikan positif terhadap pembiayaan bermasalah yang terjadi saat ini. Apabila pembiayaan bermasalah yang terjadi saat ini mengalami kenaikan, maka akan meningkatkan pembiayaan bermasalah di 3 bulan yang akan datang. Begitu pula sebaliknya, apabila pembiayaan bermasalah yang terjadi saat ini berkurang, maka pembiayaan bermasalah di 3 bulan ke depan juga ikut berkurang. Hasil ini dikuatkan oleh temuan Gerlach, Peng, \& Shu (2003), Jiménez \& Saurina (2006), Makri, Tsagkanos, \& Bellas (2014) yang menyatakan bahwa tingkat risiko kredit yang terjadi saat ini dipengaruhi oleh risiko kredit yang terjadi di masa lalu.

Meskipun dampak dari pengelolaan risiko kredit pada jangka pendek (3 bulan) di kedua kelompok bank sama, tetapi besaran nilainya berbeda. Dampak pada perbankan konvensional lebih besar daripada perbankan syariah. Hal ini menunjukkan bahwa pada perbankan konvensional pengaruh pembiayaan bermasalah pada waktu yang lalu akan lebih signifikan terasa jika dibandingkan dengan pembiayaan bermasalah pada perbankan syariah. Sebagai ilustrasi, jika kemampuan masing-masing kelompok perbankan dalam mengurangi pembiayaan bermasalahnya sama maka perbankan konvensional akan lebih merasakan dampak berkurangnya pembiayaan bermasalah itu dibandingkan perbankan syariah. Begitu pula sebaliknya, jika terjadi peningkatan pembiayaan bermasalah yang sama, maka perbankan konvensional akan lebih tinggi peningkatan pembiayaan bermasalahnya dibandingkan perbankan syariah.

Perbedaan lain dari pengaruh pembiayaan bermasalah di masa yang lalu juga terlihat dari periodenya. Pada saat kredit bermasalah perbankan konvensional hanya dipengaruhi oleh kredit bermasalah di 3 bulan yang lalu, lain halnya dengan pembiayaan bermasalah perbankan syariah yang dipengaruhi oleh pembiayaan bermasalah di 3 triwulan yang lalu secara berturut-turut. Hal ini mengindikasikan bahwa, pengelolaan risiko kredit di bank syariah lebih sulit jika dibandingkan dengan bank konvensional, karena pengelolaan risiko kredit di bank syariah harus lebih rinci dalam mempertimbangkan risiko kredit yang muncul di masa-masa yang lalu. Hal ini juga mengindikasikan bahwa dalam waktu yang relatif singkat (3 bulan) kelompok perbankan konvensional sudah dapat melakukan pengendalian terhadap risiko yang akan terjadi. Sedangkan kelompok perbankan syariah membutuhkan waktu lebih banyak untuk melalukan pengendalian terhadap risiko yang terjadi.

Adanya hubungan positif antara siklus kredit dan risiko kredit seperti yang diungkapkan oleh Jiménez \& Saurina (2006) menguatkan hasil temuan penelitian ini. Adanya peningkatan yang cepat dalam portofolio utang memiliki hubungan positif dengan peningkatan rasio NPL di kemudian hari. Pengendalian risiko dengan memperhatikan pembiayaan bermasalah yang ditimbulkan pada masa 


\section{Perbandingan Pengelolaan Risiko Kredit Perbankan Syariah dan Perbankan Konvensional \\ Muhammad Iqbal}

lalu berbeda perlakuannya dengan pertumbuhan pembiayaan yang disalurkan oleh kedua kelompok bank. Jika pembiayaan bermasalah di masa lalu pada kedua kelompok bank sama pengaruhnya terhadap risiko kredit, maka pertumbuhan pembiayaan yang disalurkan tidak sama pengaruhnya terhadap risiko kredit. Pada perbankan konvensional pertumbuhan pembiayaan sama sekali tidak dapat dijadikan instrumen dalam pengelolaan risiko kredit. Sedangkan pada perbankan syariah, pertumbuhan pembiayaan dapat dijadikan alat dalam mengendalikan risiko kredit yang akan terjadi. Perbankan syariah dapat menekan risiko kredit yang terjadi di masa depan dengan cara meningkatkan pertumbuhan kredit saat ini. Peningkatan pertumbuhan kredit saat ini dapat menekan risiko kredit yang akan terjadi pada 6 bulan ke depan, bahkan juga dapat menekan risiko kredit yang terjadi saat ini.

Pertumbuhan DPK di bank syariah dan bank konvensional sama-sama menjadi indikator bagi risiko kredit. Seperti yang diungkapkan oleh Hartono (2006) bahwa pertumbuhan DPK dapat mendorong timbulnya pembiayaan bermasalah. Pertumbuhan DPK yang terjadi saat ini dapat dijadikan indikator dalam mengontrol risiko kredit yang muncul di 9 bulan ke depan. Pertumbuhan DPK yang sudah terlalu tinggi akan meningkatkan risiko kredit baik di bank syariah maupun di bank konvensional. Apabila pengaruh pertumbuhan DPK di bank konvensional hanya berdampak pada 9 bulan ke depan, lain halnya dengan bank syariah. Pada bank syariah pertumbuhan DPK selain berdampak pada 9 bulan ke depan juga berdampak pada setahun ke depan, hanya saja memiliki dampak yang berbeda. Dalam setahun ke depan pertumbuhan DPK dapat menekan risiko kredit di perbankan syariah. Besarnya dampak pertumbuhan DPK di 9 bulan ke depan dan setahun ke depan relatif sama.

Aset sebagai cerminan ukuran dari masingmasing kelompok perbankan dapat dijadikan indi- kator pengendalian timbulnya risiko kredit. Bertambahnya aset bank dalam jangka panjang (setahun ke depan) menimbulkan potensi risiko kredit yang lebih tinggi di kedua kelompok bank. Temuan ini dikuatkan oleh Barus \& Erick (2017) yang menyatakan bahwa ukuran perusahaan berpengaruh signifikan positif terhadap NPL. Walaupun demikian hasil ini bertentangan dengan temuan penelitian lainnya, seperti Firmansyah (2014) dan Riyadi, Iqbal, \& Lauren (2015).

Jenuhnya industri perbankan konvensional memberikan dampak yang kurang sehat bagi pengelolaan risiko kredit, berbeda dengan industri perbankan syariah. Walaupun dalam jangka panjang pertumbuhan aset akan menimbulkan risiko kredit, tetapi hal ini dapat ditekan dalam jangka pendek. Usaha menekan timbulnya risiko kredit pada perbankan syariah dapat dilakukan dengan cara mendorong pertumbuhan aset dalam periode yang lebih singkat. Bertambahnya aset perbankan syariah di 3 bulan yang lalu akan menekan potensi risiko kredit saat ini. Bahkan dampak pengaruh jangka pendeknya lebih besar hampir 2 kali lipat dibandingkan pengaruh jangka panjangnya.

Setelah mengetahui persamaan dan perbedaan dari pengaruh kinerja masing-masing kelompok bank, pembahasan selanjutnya fokus pada pengaruh variabel makroekonomi terhadap risiko kredit di masing-masing kelompok bank. Pendapatan nasional memiliki pengaruh yang sama antara perbankan syariah dan perbankan konvensional dalam memicu timbulnya risiko kredit, yang dalam hal ini diukur dengan pembiayaan bermasalah. Tumbuhnya pendapatan nasional di 3 bulan yang lalu akan menekan timbulnya risiko kredit pada perbankan syariah dan perbankan konvensional di masa kini. Hal ini mengindikasikan bahwa perbaikan kondisi makroekonomi ikut meningkatkan kinerja dunia perbankan. Besarnya dampak kenaikan pendapatan nasional 3 bulan yang lalu dalam meminimalisir risiko kredit di perbankan syariah lebih kecil dibandingkan di per- 


\section{Jurnal Keuangan dan Perbankan | PERBANKAN}

Vol. 21, No. 3, Juli 2017: 481- 497

bankan konvensional di masa kini. Ini sejalan dengan fakta bahwa pangsa pasar bank konvensional yang jauh lebih besar dibandingkan dengan bank syariah. Perubahan kondisi ekonomi akan lebih dirasakan pada industri yang lebih besar. Jika kondisi ekonomi suatu negara mengalami perbaikan maka industri perbankan yang lebih besar, dalam hal ini perbankan konvensional, yang lebih merasakan manfaatnya. Begitu pula sebaliknya, jika kondisi ekonomi suatu negara mengalami penurunan, maka industri perbankan konvensional yang lebih besar mengalami kerugiannya. Hasil ini sejalan dengan temuan Messai \& Jouini (2013), Makri, Tsagkanos, \& Bellas (2014), Skarica, 2014, Vatansever \& Hepsen (2015), serta Ikram et al. (2016), yang menyatakan bahwa perlambatan ekonomi merupakan penyebab utama tingginya tingkat NPL. Sedangkan menurut Firmansyah (2014) serta Havidz \& Setiawan (2015) melemahnya pertumbuhan pendapatan nasional ikut menekan tingginya NPF pada perbankan syariah.

Meskipun sama-sama memiliki pengaruh dari pendapatan nasional dalam 3 bulan ke depan, tetapi perbankan syariah memiliki pengaruh yang lebih konsisten pada triwulan-triwulan selanjutnya. Dampak pertumbuhan pendapatan nasional terhadap munculnya risiko kredit di perbankan konvensional hanya pada 3 bulan ke depan. Sedangkan pada perbankan syaraiah, dampak pertumbuhan pendapatan nasional terhadap risiko kredit dirasakan pada periode yang sama, pada 9 bulan ke depan dan pada setahun ke depan. Seperti pada 3 bulan ke depan, tumbuhnya pendapatan nasional di periode-periode ke depan ( 9 bulan dan setahun ke depan) konsisten menurunkan risiko kredit. Dampak terbesar ada pada setahun ke depannya. Sedangkan bertambahnya pendapatan nasional saat ini mengakibatkan tingginya risiko kredit di perbankan syariah pada periode yang sama.

Tingkat suku bunga acuan yang diproksi dengan BI rate akan memengaruhi jumlah kredit yang disalurkan oleh perbankan konvensional, sehingga secara tidak langsung juga akan memengaruhi pembiayaan bermasalah sebagai proksi dari risiko kredit. Berbeda dengan bank konvensional, bank syariah tidak mengenal sistem bunga, jadi besar kecilnya tingkat suku bunga acuan tidak seharusnya berdampak pada jumlah pembiayaan yang disalurkan oleh bank syariah sehingga tidak juga berdampak pada pembiayaan bermasalah. Tapi hal ini tidaklah berlaku mengingat Indonesia menganut dual banking system yang mana sistem bunga bagi perbankan konvensional dan sistem bagi hasil bagi perbankan syariah. Artinya konsumen bebas menggunakan jasa perbankan mana saja. Ditambah dengan perilaku konsumen yang cenderung rasional, sehingga perubahan tingkat suku bunga mau tidak mau akan memengaruhi sebagian besar perilaku nasabah di bank syariah yang pada akhirnya ikut memengaruhi pembiayaan bermasalahnya. Ikut meningkatnya risiko kredit akibat tingginya pertumbuhan kredit dikuatkan oleh penelitian Messai \& Jouini (2013), Vatansever \& Hepsen (2015), serta Barus \& Erick (2017). Mereka menemukan bahwa tingkat suku bunga berpengaruh positif terhadap rasio pembiayaan bermasalah.

Efek tingkat suku bunga pada perbankan syariah dan perbankan konvensional relatif tidak memiliki kemiripan. Pada perbankan syariah, pengaruh tingkat suku bunga mengalami perubahan pada 6 bulan dan 9 bulan ke depan sedangkan pada perbankan konvensional tingkat suku bunga berpengaruh pada 3 bulan ke depan dan setahun ke depan. Akhirnya pola pengaruhnya saja yang sama pada kedua kelompok bank tersebut. Awalnya kenaikan suku bunga akan memicu timbulnya pembiayaan bermasalah, tetapi di periode berikutnya kenaikan suku bunga menekan timbulnya risiko kredit. Pada bank syariah hal ini terjadi lebih cepat, yaitu pada 6 bulan dan 9 bulan berikutnya.

Sedangkan pada bank konvensional pola pengaruh ini terjadi pada periode saat ini dan setahun ke depan. Hal ini mengindikasikan bahwa risiko kredit bank syariah hanya sensitif sesaat pada 


\section{Perbandingan Pengelolaan Risiko Kredit Perbankan Syariah dan Perbankan Konvensional \\ Muhammad Iqbal}

perubahan tingkat suku bunga, sedangkan bank konvensional lebih cepat sensitif dan memiliki efek jangka panjang. Pola ini juga yang nantinya akan memengaruhi pengelolaan risiko kredit pada perbankan syariah dan konvensional. Bank syariah tidak perlu terlalu panik dalam menangani perubahan tingkat suku bunga acuan karena sifatnya yang sementara. Sedangkan bank konvensional perlu penangganan lebih intensif dalam menyikapi perubahan tingkat bunga dalam rangka menjaga risiko kredit yang masih dalam batas kewajaran.

Variabel terakhir yang menjadi pengamatan dalam mengelola risiko kredit adalah tingkat inflasi. Pada perbankan syariah, inflasi dimasamasa lalu secara konsisten berdampak pada risiko kredit. Temuan ini dikuatkan oleh Firmansyah (2014) yang menyatakan bahwa inflasi berpengaruh signifikan terhadap rasio pembiayaan bermasalah di bank syariah. Sedangkan pada perbankan konvensional, hanya inflasi di periode yang sama saja yang dapat dijadikan indikator pengelolaan risiko kredit. Kuatnya pengaruh inflasi pada risiko kredit di bank konvensional seperti yang pernah ditemukan penelitian sebelumnya oleh Skarica (2014) serta Barus \& Erick (2017). Meskipun demikian, hasil ini tetap tidak sejalan dengan temuan Havidz \& Setiawan (2015) serta Laryea, NtowGyamfi, \& Alu (2016) yang menyatakan bahwa inflasi tidak berpengaruh signifikan terahadap NPL.

Inflasi yang tinggi disuatu negara akan mengakibatkan turunnya kredit bermasalah di bank konvensional. Sedangkan inflasi yang rendah akan meningkatkan naiknya pembiayaan bermasalah di bank konvensional. Pola pengaruh inflasi terhadap risiko kredit di bank syariah berfluktuasi, di awal periode kenaikan inflasi akan memicu tingginya pembiayaan bermasalah, sedangkan di tengah periode kenaikan inflasi akan meredam timbulnya pembiayaan bermasalah, dan di akhir periode kenaikan inflasi kembali memicu tingginya pembiayaan bermasalah. Hasil ini menunjukkan bahwa inflasi hanya berdampak sesaat pada perbankan konvensional dan berdampak terus menerus terhadap perbankan syariah. Artinya penanganan fenomena inflasi sebagai indikator makroekonomi harus lebih dipantau oleh perbankan syariah sebagai upaya mengendalikan tingginya pembiayaan bermasalah.

\section{SIMPULAN DAN SARAN}

\section{Simpulan}

Berdasarkan hasil penelitian dan analisis pembahasan yang dilakukan dalam penelitian ini, ada beberpa kesimpulan yang dapat diambil, antara lain adalah: (1) pembiayaan bermasalah yang timbul pada periode sebelumnya akan memicu risiko kredit yang lebih besar lagi di periodeperiode yang akan datang, baik itu pada perbankan syariah maupun perbankan konvensional; (2) pertumbuhan kredit di bank konvensional tidak dapat dijadikan indikator dalam mengontrol risiko kredit yang muncul, sedangkan pertumbuhan pembiayaan di bank syariah dapat dijadikan indikator dalam mengontrol risiko kredit yang muncul; (3) pertumbuhan DPK dan aset dapat dijadikan instrumen pengendalian risiko kredit di bank syariah dan bank konvensional dengan pola yang relatif sama. Hanya saja pertumbuhan DPK dan aset bank konvensional memiliki pengaruh yang lebih panjang periodenya terhadap timbulnya risiko kredit dibandingkan bank syariah; dan (4) selain kinerja bank, indikator makroekonomi, seperti pendapatan nasional, perubahan tingkat suku bunga dan tingkat inflasi merupakan faktor penentu pengelolaan risiko kredit di perbankan syariah maupun perbankan konvensional. Risiko kredit di perbankan syariah jauh lebih sensitif terhadap perubahan indikator makroekonomi dibandingkan dengan risiko kredit di perbankan konvensional. 


\section{Jurnal Keuangan dan Perbankan | PERBANKAN}

Vol. 21, No. 3, Juli 2017: 481-497

\section{Saran}

Berdasarkan analisis dan kesimpulan dari penelitian yang dilakukan, ada beberapa saran yang dihasilkan pada penelitian ini, antara lain: (1) dalam rangka menekan timbulnya risiko kredit yang lebih besar di kemudian hari, baik perbankan syariah maupun perbankan konvensional harus berusaha menekat tingginya angka pembiayaan bermasalah; (2) selain menjaga kualitas pembiayaan, bank syariah juga perlu memacu pertumbuhan pembiayaan, karena dengan terus meningkatkan pertumbuhan pembiayaan maka secara tidak langsung perbankan syariah berusaha mengurangi timbulnya pembiayaan bermasalah; dan (3) penggunaan indikator kinerja internal bank dan indikator makroekonomi dalam mengendalikan timbulnya risiko kredit perlu disesuaikan dengan besaran dampak yang ditimbulkan dari masingmasing indikator dan jangka waktu dari efek tersebut, sehingga pengelolaan risiko kredit dapat dilakukan secara terencana.

\section{DAFTAR PUSTAKA}

Almon, S. 1965. The Distributed Lag between Capital Appropriations and Expenditures. Econometrica, 33(1): 178-196.

Bank Indonesia, Statistika Perbankan Syariah 2001-2012.

Bank Indonesia, Statistika Perbankan Indonesia 2001-2012.

Barus, A.C. \& Erick. 2017. Analisis Faktor-Faktor yang Memengaruhi Non Performing Loan pada Bank Umum di Indonesia. JWEM (Jurnal Wira Ekonomi Mikroskil), 6(2): 113-122.

Borio, C., Furfine, C., \& Lowe, P. 2001. Procyclicality of the Financial System and Financial Stability: Issues and Policy Options. Marrying the Macro- and Micro- Prudential Dimensions of Financial Stability, 1: 1-57.

Chaibi, H. 2016. Determinants of Problem Loans: Nonperforming Loans vs. Loan Quality Deterioration. International Business Research, 9(10): 86-93.
Firmansyah, I. 2014. Determinant of Non Performing Loan: The Case of Islamic Bank in Indonesia. Bulletin of Monetary Economics and Banking, 17(2): 241258.

Gerlach, S., Peng, W., \& Shu, C. 2003. Macroeconomic Conditions and Banking Performance in Hong Kong SAR: A Panel Data Study. Investigating the Relationship between the Financial and Real Economy, 22: 481-497.

Gujarati, D. \& Porter, D. 2008. Basic Econometrics. Fifth Edition. Boston: McGraw-Hill Education.

Hartono. 2006. Pengaruh DPK dan SBI terhadap NPF BMI. Tesis. Fakultas Ekonomi Universitas Indonesia.

Havidz, S.A.H. \& Setiawan, C. 2015. Bank Efficiency and Non-Performing Financing (NPF) in the Indonesian Islamic Banks. Asian Journal of Economic Modelling, 3(3): 61-79.

Ikram, A., Su, Q., Ijaz, F., \& Fiaz, M. 2016. Determinants of Non-Performing Loans: An Empirical Investigation of Bank-Specific Micro-Economic Factors. Journal of Applied Business Research (JABR), 3(10): 17231736.

Jiménez, G. \& Saurina, J. 2006. Credit Cycles, Credit Risk, and Prudential Regulation. International Journal of Central Banking, 2(2): 1815-4654.

Laryea, E., Ntow-Gyamfi, M., \& Alu, A.A. 2016. Nonperforming Loans and Bank Profitability: Evidence from an Emerging Market. African Journal of Economic and Management Studies, 7(4): 462-481.

Makri, V., Tsagkanos, A., \& Bellas, A. 2014. Determinants of Non-Performing Loans: The Case of Eurozone. Panoeconomicus, 61(2): 193-206.

Messai, A.S. \& Jouini, F. 2013. Micro and Macro Determinants of Non-performing Loans. International Journal of Economics and Financial Issues, 3(4): 852-860.

Mutamimah, M. \& Chasanah, S.N.Z. 2012. Analisis Eksternal dan Internal dalam Menentukan Non Performing Financing Bank Umum Syariah di Indonesia. Jurnal Bisnis dan Ekonomi, 19(1): 46-64.

Nuryartono, N., Saptono, I.T., \&Was'an, G.H. 2016. Kaitan Kondisi Makroekonomi dengan Non Performing Financing Berdasarkan Sektor Ekonomi pada 


\section{Perbandingan Pengelolaan Risiko Kredit Perbankan Syariah dan Perbankan Konvensional}

Muhammad Iqbal

Perbankan Syariah di Indonesia. Jurnal Keuangan dan Perbankan, 20(1): 104-115.

Otoritas Jasa Keuangan, Statistika Perbankan Syariah 20132016.

Otoritas Jasa Keuangan, Statistika Perbankan Indonesia 2013-2016.

Riyadi, S. 2011. Banking Asset and Liability Management. Third Edition. Jakarta: Lembaga Penerbit Fakultas Ekonomi Universitas Indonesia.

Riyadi, S., Iqbal, M., \& Lauren, N. 2015. Strategi Pengelolaan Non Performing Loan (NPL) Bank Umum yang Go Public. Jurnal Dinamika Manajemen, 6(1): 84-96.
Rokhim, R. \& Yanti, M.I.S.M. 2014. Risiko NPL Kredit Bank Pembangunan Daerah Sebagai Regional Champion. Jurnal Keuangan dan Perbankan (JKP), 18(1): $120-129$.

Skarica, B. 2014. Determinants of Non-Performing Loans in Central and Eastern European Countries. Financial Theory and Practice, 38(1): 37-59.

Sugiyono. 2014. Metode Penelitian Manajemen. Bandung: Alfabeta.

Vatansever, M. \& Hepsen, A. 2013. Determining Impacts on Non-Performing Loan Ratio in Turkey. Journal of Finance and Investment Analysis, 2(4): 119-129. 